\title{
Phenylpyrroles: 30 Years, Two Molecules and (Nearly) No Resistance
}

\author{
Jaafar Kilani ${ }^{1,2 *}$ and Sabine Fillinger ${ }^{1}$ \\ ${ }^{1}$ UMR BIOGER, Institut National de la Recherche Agronomique, AgroParisTech, Université Paris Saclay, Thiverval-Grignon, \\ France, ${ }^{2}$ Université Paris-Sud, Université Paris-Saclay, Orsay, France
}

Phenylpyrroles are chemical analogs of the natural antifungal compound pyrrolnitrin. Fenpiclonil, but mainly fludioxonil are registered against multiple fungal crop diseases since over 25 years for seed or foliar treatment. They have severe physiological impacts on the pathogen, including membrane hyperpolarization, changes in carbon metabolism and the accumulation of metabolites leading to hyphal swelling and burst. The selection and characterization of mutants resistant to phenylpyrroles have revealed that these fungicides activate the fungal osmotic signal transduction pathway through their perception by a typical fungal hybrid histidine kinase $(\mathrm{HHK})$. The HHK is prone to point mutations that confer fungicide resistance and affect its sensor domain, composed of tandem repeats of HAMP motifs. Fludioxonil resistant mutants have been selected in

OPEN ACCESS

Edited by:

Miguel Cacho Teixeira University of Lisbon, Portugal

Reviewed by:

Yong-Sun Bahn, Yonsei University, South Korea Nicolas Papon,

University of Angers, France

${ }^{*}$ Correspondence: Jaafar Kilan jaafar.kilani@inra.fr

Specialty section:

This article was submitted to Antimicrobials, Resistance and Chemotherapy, a section of the journal Frontiers in Microbiology

Received: 29 September 2016 Accepted: 01 December 2016 Published: 16 December 2016

Citation:

Kilani J and Fillinger S (2016) Phenylpyrroles: 30 Years, Two

Molecules and (Nearly) No Resistance. Front. Microbiol. 7:2014. doi: 10.3389/fmicb.2016.02014 many fungal species under laboratory conditions. Generally they present severe impacts on fitness parameters. Since only few cases of field resistance specific to phenylpyrroles have been reported one may suspect that the fitness penalty of phenylpyrrole resistance is the reason for the lack of field resistance.

Keywords: fungicide, signal transduction, histidine kinase, resistance, fitness

\section{THE ORIGIN OF PHENYLPYRROLES}

Phenylpyrroles are chemical derivatives of pyrrolnitrin, a secondary metabolite produced by some bacteria from tryptophan (Floss et al., 1971). It was isolated for the first time from Pseudomonas pyrrocinia in the 1960s (Arima et al., 1965) and showed strong antifungal activity against various animal and plant pathogenic fungi even under greenhouse conditions. Pyrrolnitrin or pyrrolnitrin producing Pseudomonas (e.g., P. fluorescens) proved phytoprotecting efficiency against Rhizoctonia solani, Alternaria sp., Fusarium sp., Verticillium dahliae, and Thielaviopsis basicola. Its activity was found stable for 30 days in the soil (Howell and Stipanovic, 1979) but sensitive to light decomposition. Consequently, two synthetic analogs have been successfully developed by CibaGeigy AG (now Syngenta AG) in the 1980s and introduced in the market for seed treatment and foliar use (reviewed in Leadbitter et al., 1994).

Fenpiclonil and fludioxonil are 3-cyano-4-phenylpyrrol analogs of pyrrolnitrin with largely increased photo-stability and similar antifungal activity (reviewed in Corran et al., 2008). These compounds differ by the substitutions at positions 2 and 3 of the phenyl ring (Figure 1). Fenpiclonil

Abbreviations: HAMP domain: domains conserved among histidine kinase, adenylate cyclase, methyl accepting proteins, phosphatases; HHK: hybrid histidine kinase; HK: histidine kinase; MAPK: mitogen activated kinase; PK-III: protein kinase III; ST: signal transduction. 
<smiles>O=[N+]([O-])c1c(Cl)cccc1-c1c[nH]cc1Cl</smiles>

pyrrolnitrin<smiles>N#Cc1c[nH]cc1-c1cccc(Cl)c1Cl</smiles>

fenpiclonil<smiles></smiles>

fludioxonil

FIGURE 1 | Chemical structure of Pyrrolnitrin (Imanaka et al., 1965) and synthetic analogs (www.frac.org). The chemical characteristics of phenylpyrroles are the phenyl ring with substitutions in positions 2 and/or 3 and the pyrrole ring with substitutions at position 3 (Corran et al., 2008).

(synthetized in 1984) was introduced in the market as seedtreatment in 1988 but rapidly superseded (1990) by the more stable and more active fludioxonil as foliar and seed-treatment (Leadbitter et al., 1994; Corran et al., 2008). To date, fludioxonil can be considered as major representative of the phenylpyrrole family of fungicides.

As non-systemic, surface fungicide, fludioxonil is registered for treatments at pre- and post-harvest stages on leaves, fruits and seeds. It has a principally prophylactic action against multiple fungal diseases provoked by ascomycetes or basidiomycetes. The list of crops registered for the use of fludioxonil and the associated pathogens (if known) is indicated in Table 1. Fludioxonil has no detectable activity on non-target organisms, such as baker's yeast, men, plants, or animals (Gehmann et al., 1990).

Phenylpyrroles inhibit all stages of fungal development, spore germination, germ-tube elongation, and mycelial growth (Leroux et al., 1992). The observed consequences are swollen hyphae with increased ramifications and apical lysis (Leroux, 1996) indicating that phenylpyrroles might act on the intra-hyphal turgor and cell wall biosynthesis (Lew, 2010).

\section{EFFECT OF PHENYLPYRROLES ON TARGET FUNGI - MODE OF ACTION}

Jespers et al. (1994) observed extremely rapid intracellular accumulation of fenpiclonil in Fusarium sulphureum reaching its maximum in less than $1 \mathrm{~min}$. Interestingly, the majority of the accumulated fenpiclonil can be washed off by water, suggesting that the phenylpyrrole penetrates the fungus through passive diffusion. The same study also showed that during the exposure to fenpiclonil the fungus accumulates the lipophilic cation tetraphenylphosphonium bromide $\left(\mathrm{TPP}^{+}\right)$, independent of extracellular $\mathrm{pH}$, indicating hyperpolarization of the plasma membrane and modification of the mitochondrial membrane potential (Jespers et al., 1994). Similar results have been observed with fludioxonil in Neurospora crassa, i.e., the induction of hyperpolarization of the plasma membrane through efflux of $\mathrm{H}^{+}$ and influx of $\mathrm{K}^{+}$leading to increased membrane potential (Lew, 2010).

Various authors have observed modifications in the intracellular accumulation of different metabolites (e.g., F. sulphureum, N. crassa). Exposure to high doses of fenpiclonil (over 10-fold $\mathrm{EC}_{50}$ concentrations) induces the accumulation of amino acids and monosaccharides (Jespers et al., 1993). Conversely the exposure to sub-lethal doses of phenylpyrroles seems to inhibit the incorporation of mono-saccharides into macromolecules (Jespers and De Waard, 1994) but also to stimulate biosynthesis and intracellular accumulation of glycerol and mannitol (Jespers and De Waard, 1995; Pillonel and Meyer, 1997). In order to precise the enzymatic step inhibited by phenylpyrroles, Jespers and De Waard (1995), studied the fate of radioactively labeled 2-deoxyglucose. 2-deoxyglucose can be phosphorylated as is glucose, but cannot be further metabolized. In the presence of fenpiclonil, $\left[{ }^{14} \mathrm{C}\right]$-2-deoxyglucose accumulated intracellularly, while the intracellular concentration of $\left[{ }^{14} \mathrm{C}\right]$-2-deoxyglucose-phosphate diminished indicating the inhibition of hexokinase activity during exposure of the mycelium to the phenylpyrrole. When the authors performed the same assay on crude mycelial extracts, they only observed a minor reduction of $\left[{ }^{14} \mathrm{C}\right]-2$ deoxyglucose phosphorylation under high concentrations of fenpiclonil, withdrawing the cytoplasmic hexokinase as sole or direct target of fenpiclonil (Jespers and De Waard, 1995).

Pillonel and Meyer tested the inhibition of protein kinase activities in $N$. crassa by phenylpyrroles. They found that purified PK-III was inhibited by fenpiclonil and fludioxonil (Pillonel and Meyer, 1997). Although the concentration of phenylpyrroles required for PK-III inhibition was found similar to that of rat PKC-inhibition, N. crassa PK-III does not seem to be neither a $\mathrm{Ca}^{2+} /$ calmodulin nor a cAMP regulated protein kinase (Judewicz et al., 1981; Ulloa et al., 1987). To some extend the inhibition of PK-III correlated with growth inhibition by fenpiclonil, but less by fludioxonil, raising the question if phenylpyrroles, especially fenpiclonil, directly inhibit PK-III activity. Given the data of Pillonel and Meyer, this hypothesis has never been retained nor validated, since the concentrations required to inhibit the purified enzyme $\left(\mathrm{I}_{50}\right)$ were much higher (up to 100 times in the case of fludioxonil) than those needed to inhibit fungal growth $\left(\mathrm{EC}_{50}\right)$. Either phenylpyrroles do not inhibit PK-III by itself, acting rather indirectly, or they may affect different cellular targets. 
TABLE 1 | Crops and diseases registered for pre- or pos-tharvest treatment with phenylpyrroles.

\begin{tabular}{|c|c|c|}
\hline Crop & Pathogens controlled & Reference \\
\hline \multicolumn{3}{|c|}{ Seed treatments and post-harvest uses } \\
\hline Almonds & $\begin{array}{l}\text { Coryneum beijerinckii, } \\
\text { Monilinia spp. }\end{array}$ & Gehmann et al., 1990 \\
\hline \multirow[t]{5}{*}{ Avocado } & Dothiorella iberica & Twizeyimana et al., 2013 \\
\hline & Neofusicoccum australe & \\
\hline & Neofusicoccum luteum & \\
\hline & Neofusicoccum parvum & \\
\hline & Phomopsis spp. & \\
\hline \multirow[t]{5}{*}{ Barley } & Microdochium nivale & Gehmann et al., 1990 \\
\hline & Fusarium spp. & \\
\hline & Ustilago hordei & \\
\hline & Pyrenophora graminea & \\
\hline & Cochliobolus sativus & \\
\hline \multirow[t]{2}{*}{ Beans } & Rhizoctonia solani & Olaya et al., 1994 \\
\hline & Botrytis spp. & Gehmann et al., 1990 \\
\hline Carrot & $n . i^{*}$ & \\
\hline Citrus fruit & Penicillium digitatum & Kanetis et al., 2007 \\
\hline \multirow[t]{3}{*}{ Cotton } & Fusarium spp. & Leroux et al., 1992; \\
\hline & Rhizoctonia solani & Corran et al., 2008 \\
\hline & Thielaviopsis basicola & \\
\hline Cucurbit vegetables & $n . i$ & \\
\hline Eggplant & Botrytis spp. & Corran et al., 2008 \\
\hline Flax seed & $n . i^{*}$ & \\
\hline $\begin{array}{l}\text { Foliage of legume } \\
\text { vegetables }\end{array}$ & $n . i^{*}$ & \\
\hline Ginseng & $n . i^{*}$ & \\
\hline \multirow[t]{2}{*}{ Grapes } & Botrytis cinerea & Gehmann et al., 1990 \\
\hline & Glomerella cingulata & \\
\hline $\begin{array}{l}\text { Grass (forage, fodder, } \\
\text { hay) }\end{array}$ & $n . i^{*}$ & \\
\hline Jojoba & $n . i^{*}$ & \\
\hline Kiwifruit & Botrytis cinerea & Brigati et al., 2009 \\
\hline Lettuce & Sclerotinia minor & Gehmann et al., 1990 \\
\hline Maize & Fusarium graminearum & Gehmann et al., 1990 \\
\hline Tropical fruits & $n \cdot i^{*}$ & \\
\hline \multirow[t]{2}{*}{ Peanut } & Sclerotinia minor & Gehmann et al., 1990; \\
\hline & Rhizoctonia solani & Corran et al., 2008 \\
\hline \multirow[t]{3}{*}{ Peas } & Ascochyta spp. & Gehmann et al., 1990; \\
\hline & Fusarium spp. & Corran et al., 2008 \\
\hline & Peyronellaea pinodes & \\
\hline Pineapple & $n . i^{*}$ & \\
\hline Pistachio & Alternaria spp. & Ma et al., 2004 \\
\hline Pome fruit & $\begin{array}{l}\text { Penicillium spp., Botrytis } \\
\text { cinerea }\end{array}$ & $\begin{array}{l}\text { Errampalli, 2004; Zhao } \\
\text { et al., } 2010\end{array}$ \\
\hline \multirow[t]{3}{*}{ Pomegranate } & Botrytis cinerea & Palou et al., 2007; \\
\hline & Alternaria spp. & D’Aquino et al., 2010 \\
\hline & Penicillium spp. & \\
\hline \multirow[t]{5}{*}{ Potato } & Fusarium spp. & Gehmann et al., 1990; \\
\hline & Helminthosporium solani & Gachango et al., 2012 \\
\hline & Boeremia exigua & \\
\hline & Rhizoctonia solani & \\
\hline & Alternaria solani & \\
\hline Rapeseed & Leptosphaeria maculans & Gehmann et al., 1990; \\
\hline
\end{tabular}

(Continued)
TABLE 1 | Continued

\begin{tabular}{lll}
\hline Crop & Pathogens controlled & Reference \\
\hline & $\begin{array}{ll}\text { Alternaria brassicae } \\
\text { Sclerotinia sclerotiorum }\end{array}$ & Duan et al., 2013 \\
& Gibberella fujikuroi & Gehmann et al., 1990 \\
Rice & Rhizoctonia solani & \\
& Gaeumannomyces oryzinus & \\
& Cochliobolus miyabeanus & \\
& Microdochium nivale & Gehmann et al., 1990; \\
Rye & Urocystis occulta & Corran et al., 2008 \\
& Monographella nivalis &
\end{tabular}

\begin{tabular}{|c|c|c|}
\hline Safflower & $n . i^{*}$ & \\
\hline \multirow[t]{3}{*}{ Soybean } & Fusarium spp. & Mueller et al., 1999; \\
\hline & Sclerotinia sclerotiorum & Corran et al., 2008 \\
\hline & Rhizoctonia solani & \\
\hline $\begin{array}{l}\text { Stone fruits (apricots, } \\
\text { peaches, nectarines, } \\
\text { cherries, plums) }\end{array}$ & $\begin{array}{l}\text { Monilinia spp., Botrytis } \\
\text { cinerea, Rhizopus spp. }\end{array}$ & $\begin{array}{l}\text { Gehmann et al., 1990; } \\
\text { Förster et al., } 2007\end{array}$ \\
\hline \multirow[t]{2}{*}{ Strawberry } & Botrytis cinerea & Gehmann et al., 1990; \\
\hline & Glomerella cingulata & Taguchi et al., 2012 \\
\hline Sunflower & $n . i^{*}$ & \\
\hline Sweet potato & Rhizopus stolonifer & $\begin{array}{l}\text { Edmunds and Holmes, } \\
2009\end{array}$ \\
\hline Tomato & Botrytis spp., Alternaria & Gehmann et al., 1990 \\
\hline
\end{tabular}

Tropical fruits $\quad$ n.i*

Watercress $\quad n . i^{*}$

Wheat Tilletia laevis Gehmann et al., 1990;

Microdochium nivale Corran et al., 2008

Fusarium spp.

Bipolaris sorokiniana

Phaeosphaeria nodorum

Monographella nivalis

Terrestrial non-food uses

$\begin{array}{lll}\text { Turf } & \text { Rhizoctonia solani } & \text { Gehmann et al., } 1990 \\ & \text { Sclerotinia homeocarpa } & \\ & \text { Drechslera poae } & \\ & \text { Microdochium nivale } & \\ \text { Ornamentals } & \text { Rhizoctonia solani } & \text { Gehmann et al., } 1990\end{array}$

*n.i: not indicated (crops without associated pathogens were extracted from the registration review of fludioxonil).

\section{FROM PHENYLPYRROLES TO OSMOTIC SIGNAL TRANSDUCTION}

Glycerol accumulation is a consequence specific to the exposure to phenylpyrrole, dicarboximide and aromatic hydrocarbon fungicides. The selection of laboratory generated mutants resistant to the three categories of fungicides in B. cinerea correlated with osmosensitivity (Leroux et al., 1992; Faretra and Pollastro, 1993). Also N. crassa osmosensitive mutants os-1, os-2, os-4, and os-5 (Perkins et al., 1982) are resistant to dicarboximides, aromatic hydrocarbons, and phenylpyrroles (Fujimura et al., 2000; Zhang et al., 2002). 
The corresponding genes and mutations have been cloned and identified in $N$. crass $a$ and later in other fungi. The os1 gene encodes a class III HHK (Schumacher et al., 1997) whose mutations lead to fungicide resistance and osmosensitivity (Ochiai et al., 2001). The os-2 gene on its turn encodes the osmosensing MAPK (Zhang et al., 2002), homologous to the MAPK of Saccharomyces cerevisiae involved in adaptation to high osmolarity named, high osmolarity glycerol, Hog1 (Hohmann, 2002). The fungicide resistant/osmosensitive phenotype of os-2 mutants is due to non-sense mutations. Finally, os-5 and os4 are the MAPKK and MAPKKK encoding genes, respectively (Fujimura et al., 2003). The Os-5, Os-4, and Os-2 elements are equivalent to the yeast osmotic ST cascade. Altogether these items suggest that the phenylpyrroles (and dicarboximides) target the osmotic ST cascade, in particular the class III HHK Os-1.

An additional argument for this hypothesis is the fact that the yeast S. cerevisiae, devoid of this class of HHK, is insensitive to phenylpyrroles and dicarboximides. The introduction of a class III HHK, orthologous to Os-1, leads to sensitivity to phenylpyrroles, dicarboximides and aromatic hydrocarbons in S. cerevisiae (Motoyama et al., 2005). These results are in favor of the class III HHK as direct target of phenylpyrroles (and dicarboximides).

The possible mode of action is that fludioxonil, by binding to the class III HHK, mimics an osmotic stress through the activation of the Os-2/Hog1 MAPK (Figure 2A). This activation probably leads to multiple downstream reactions, such as activation of $\mathrm{H}+$-ATPase, $\mathrm{K}+$-influx and glycerol biosynthesis leading to increased intracellular turgor and membrane potential (Lew, 2010). Additional enzyme activities may be affected, e.g., hexokinase or sugar transporters (Jespers et al., 1994; Jespers and De Waard, 1995) that ultimately explain the phenotypes outlined above.

\section{RESISTANCE TO PHENYLPYRROLES}

Until now only few cases of field resistance specific to fludioxonil have been reported; this despite the fact that for many fungal species (N. crassa, B. cinerea, S. sclerotiorum, $U$. maydis, A. nidulans,...) resistant strains could easily be obtained after mutagenesis and successive replication on fludioxonil supplemented medium (e.g., Avenot et al., 2005). These laboratory mutants display high resistance levels to phenylpyrroles, which is often associated with sensitivity to hyper-osmolarity and cross-resistance to dicarboximides and aromatic hydrocarbons (Ochiai et al., 2001; Leroux et al., 2002). In addition, most laboratory mutants, e.g., in B. cinerea and A. brassicicola, display developmental defects and reduced pathogenicity (Avenot et al., 2005; Ajouz et al., 2010; Ren et al., 2016). Adversely, no fitness penalty was found associated with dicarboximide resistance (and phenylpyrrole sensitivity) in field strains (Oshima et al., 2002, 2006). Notably, in some fungal species, no developmental defect besides osmosensitivity was found associated with phenylpyrrole resistance (Motoyama et al., 2005; Luo et al., 2012).
Field strains cross-resistant to phenylpyrroles and dicarboximides have been isolated from A. brassicicola, A. longipes, and A. alternata populations (Dry et al., 2004; Iacomi-Vasilescu et al., 2004; Avenot et al., 2005; Luo et al., 2012; Avenot and Michailides, 2015; Malandrakis et al., 2015). No significant developmental defects could be detected in the A. brassicicola resistant mutants and only moderate osmosensitivity (Avenot et al., 2005; IacomiVasilescu et al., 2008). However, phenylpyrrole resistance seems limited in Alternaria field populations (Avenot and Michailides, 2015; Malandrakis et al., 2015) indicating a potential fitness penalty not detected under controlled laboratory conditions.

Recently, fludioxonil resistant strains have been isolated from B. cinerea field populations in China, at low levels $(<3 \%)$. They present the typical osmosensitivity and developmental defects of fludioxonil resistant laboratory mutants (Ren et al., 2016) raising the question of their capacity to compete with sensitive and fitter strains and the selective pressure of fungicide treatments on these particular populations. Globally, specific resistance to fludioxonil does not exist among gray mold populations maintaining the high efficiency of this fungicide (Walker et al., 2013; Fillinger and Walker, 2016). However, multidrug resistant (MDR) phenotypes due to increased fungicide efflux affect sensitivity to fludioxonil (Kretschmer et al., 2009). Although MDR does not reach resistance levels sufficient to alter field efficacy of fungicides at their registered field rates, the MDR1h phenotype of $B$. cinerea group $\mathrm{S}$ strains leads to the highest resistance levels to fludioxonil reported for field isolates (Leroch et al., 2013) - besides the specific resistance reported from China (Ren et al., 2016) - and impacts fludioxonil efficacy at least in in vitro assays (Rupp et al., 2016).

\section{FUNGAL HISTIDINE KINASES LINKED TO PHENYLPYRROLE RESISTANCE}

As mentioned above, mutations conferring resistance to phenylpyrroles and dicarboximides map to class III HHKs, although one cannot exclude the presence of mutations in other components of the osmotic ST cascades that have not been specifically searched for. HKs are ubiquitous, but typical fungal HHKs are absent from mammals and therefore constitute interesting targets for fungicide treatments. They are involved in cellular ST systems referred to as His-to-Asp phosphorelays. HHKs act as primary sensors for various environmental signals and initiate the adaptive response after autophosphorylation and subsequent phosphotransfer (reviewed by Bahn, 2008). Interestingly, the class III HHKs were shown to be cytoplasmic (Meena et al., 2010; Foureau et al., 2014), meaning that they sense fludioxonil intracellularly after its transmembrane diffusion.

Fungal HHKs are composed of the variable $\mathrm{N}$-terminal sensor domain and the C-terminal domain, including the catalytic HK and ATPase domains that autophosphorylate the conserved 


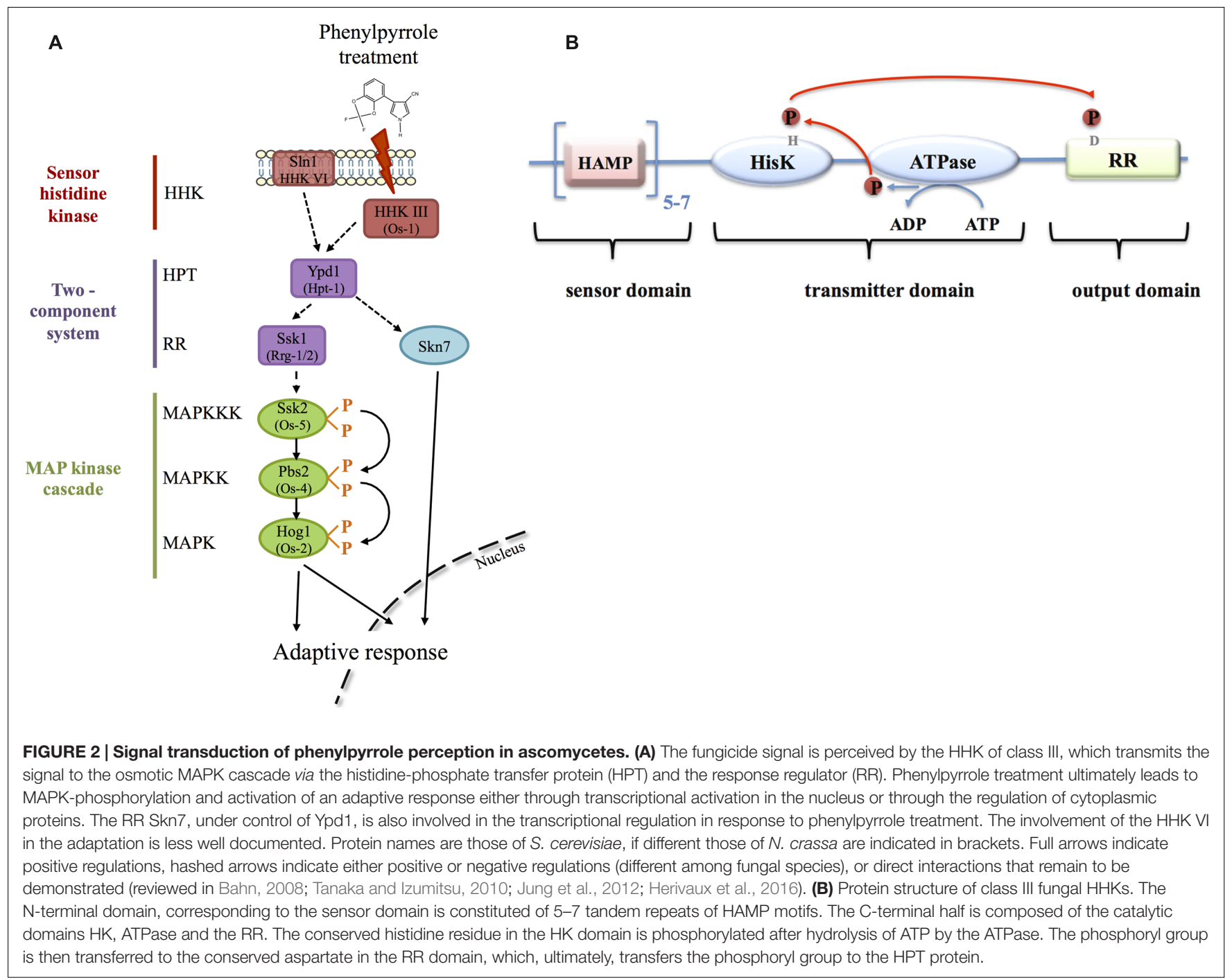

histidine residue, in addition to the receiver domain with the cognate aspartate residue (reviewed in Jung et al., 2012; Herivaux et al., 2016) (Figure 2). A classification according to the structural components of the $\mathrm{N}$-terminal domain and the peptide sequence around the conserved histidine residue attributed 16 classes of HHKs to fungi (Defosse et al., 2015). The number of HHK genes varies among species of the fungal kingdom from 1 to 21 HHKs (Catlett et al., 2003; Lavin et al., 2010; Defosse et al., 2015).

The HHKs involved in fludioxonil sensing are principally those belonging to class III (Ochiai et al., 2001; Avenot et al., 2005; Motoyama et al., 2005; Viaud et al., 2006; Dongo et al., 2009; Alberoni et al., 2010; Furukawa et al., 2012), but some data indicate a possible role in phenylpyrrole sensing of other HHKs. In Candida lusitaniae Chk1, the $\mathrm{HHK}$ of class VI, homologous to the osmosensing $\mathrm{HHK}$ $\operatorname{Sln} 1$ of $S$. cerevisiae, interferes with phenylpyrrole sensitivity (Chapeland-Leclerc et al., 2007). In the Cryptococcus neoformans, Tco2, a basidiomycete specific dual $\mathrm{HK}$ is also involved in fludioxonil sensitivity (Bahn et al., 2006). If the action of these
HHKs is direct or indirect through the HOG pathway remains to be established.

The N-terminal domain of class III HHKs is characterized by 5-7 tandem repeats of an approximately 50-amino acid alpha-helical region, conserved among several signaling proteins and named HAMP domain (IPR003660). HAMPs have been extensively studied in bacterial sensor proteins where they play an active role in the intramolecular ST from the transmembrane sensor domain to the cytoplasmic kinase domain. It has been suggested that the HAMP domain regulates the phosphorylation of homodimeric sensor proteins by transmitting the conformational changes in the ligandbinding domains to the C-terminal signaling kinase domains (Aravind and Ponting, 1999; Klose et al., 2014; Schultz et al., 2015). This model is supported by genetic and biochemical studies (Zhou et al., 2009; Matamouros et al., 2015).

Histidine kinase, adenylate cyclase, methyl accepting proteins, phosphatases modules do not have strict sequence conservation, but a canonical coiled coil structure. HAMP subunits have 
two 16-residue amphiphilic helices (AS1, AS2) joined by a 14- to 15-residue connector segment. AS1 and AS2 have a seven-residue repeat pattern with hydropic residues at the first and forth position, respectively (Parkinson, 2010). Rotation after signal perception is proposed to constitute the basic mechanism of HAMP mediated transmembrane signaling in bacteria (Airola et al., 2010, 2013; Klose et al., 2014).

The 5-7 repeats of HAMP modules and the cytoplasmic localization do not allow a simple transposition of the bacterial structure-function model to explain the mechanism of ST in fungal HKs. The number of repeat units varies across fungal species. Using $S$. cerevisiae as heterologous host the role of HAMP domains in ST has been investigated. In the case of Debaryomyces hansenii class III HHK, HAMP deletion and yeast two hybrid studies led to the proposal of a functional model to explain the transduction of the hyperosmolarity or fludioxonil signal involving the five HAMP domains of the DhNik1 protein (Meena et al., 2010; Furukawa et al., 2012): The correct order of the HAMP domains is essential; HAMP1-3, 5 are essential for kinase activity, but HAMP4 is essential for the regulation of the $\mathrm{HHK}$ in response to a signal through its interaction with HAMP5. Using this approach, the authors showed that DhNik1 in the heterologous host S. cerevisiae has a functional kinase activity under standard conditions inhibiting the phosphorylation of the MAPK Hog1. Hyperosmolarity or fludioxonil inhibit DhNik1 activity leading to Hog1 activation. The interaction between two HAMP domains (HAMP4 and HAMP5) is essential for HHK inhibition. The authors also showed in the yeast model, that a constitutive active form of DhNIK1 confers resistance to fludioxonil. Among point mutations of $N$. crassa mutants displaying low resistance to fludioxonil (Ochiai et al., 2001), at least one of these mutations leads to a constitutive active form of the class III $\mathrm{HK}$, conferring fludioxonil resistance to $S$. cerevisiae (Furukawa et al., 2012).

Mutations in fungal class III HHKs conferring resistance to phenylpyrroles and cross-resistance to dicarboximides generally induce phenotypes similar to deletion mutants (Viaud et al., 2006; Fillinger et al., 2012). They localize within or between the HAMP domains of the HHKs (Oshima et al., 2002; Alberoni et al., 2010; Fillinger et al., 2012; Firoz et al., 2015), while others are frameshift or non-sense mutations (Ochiai et al., 2001; Iacomi-Vasilescu et al., 2004; Duan et al., 2014; Ren et al., 2016). Altogether these results are in agreement with the hypothesis that in most cases loss-of-function mutations are responsible for fludioxonil resistance in plant pathogenic fungi (mainly laboratory mutants; reviewed in Defosse et al., 2015), but mutations leading to modified function or even constitutively active HHK may exist as well, probably at very low frequencies. Due to its essential role in many biological processes including pathogenicity (Viaud et al., 2006; Herivaux et al., 2016), loosing a class III HHK might explain the absence of fludioxonil field resistance in most plant pathogenic fungi.

\section{CONCLUSION}

Thirty years after their introduction in the fungicide market, the large spectrum phenylpyrroles still hide some mysteries. Although all characterized resistance mutations have been mapped to class III HHK genes, the corresponding protein has never been demonstrated as phenylpyrrole target. It has been shown that fludioxonil, the nearly unique representative of this class of fungicides, activates the osmosensing MAPK in divers fungi (Kojima et al., 2004; Yoshimi et al., 2005; Bahn et al., 2006; Hagiwara et al., 2007; Segmuller et al., 2007) which may be its real mode of action. One may hypothesize that this permanent stimulation of the hyper-osmolarity response via MAPK activation induces the observed pleiotropic phenotypes and, consequently, fungal death.

Another mystery is the absence (or low abundance) of fludioxonil field resistance. To our knowledge field isolates displaying specific resistant to fludioxonil have been detected only in Alternaria sp. (Iacomi-Vasilescu et al., 2004) and, very recently in $B$. cinerea (Ren et al., 2016). In most cases fludioxonil resistance due to mutations in the HHK gene seems to induce a strong fitness penalty; e.g., extremely reduced sporulation, osmosensitivity, loss of pathogenicity, etc. (Ziogas et al., 2005; Viaud et al., 2006; Ajouz et al., 2011; Malandrakis et al., 2015), definitely counter-selecting fludioxonil resistance. In the case of A. brassicicola, the absence of evident developmental defects in some fludioxonil resistant field isolates (Iacomi-Vasilescu et al., 2004), might be due to compensatory mutations in a given genetic background. Nevertheless spreading of these strains might be limited under field conditions due to some yet undetected defect. Therefore it might be suspected that evolution of fludioxonil resistance in fungal populations is strongly limited, unless additional mutations compensating the fitness penalty may arise and be selected. After 30 years of phenylpyrroles the chances to select such multiple mutations seem limited; otherwise they would have already appeared.

Another question raised while writing this review is the absence of alternative structural analogs of pyrrolnitrin that could have been produced by the chemical companies; an astonishing fact since fenpiclonil and fludioxonil have a large spectrum of activity, high efficiency and are not really facing resistance problems. Were similar components synthesized, but did not show comparable efficiency or stability? Are there problems with other phenylpyrroles that fenpiclonil or fludioxonil do not face? Is synthesis too complicated or expensive? At Ciba Geigy, among the multiple analogs tested, fenpiclonil and fludioxonil were the only molecules with the required properties for efficient fungicides (Leadbitter et al., 1994; Pillonel and Meyer, 1997) and their registration, suggesting potential problems in synthesis, activity, stability, and/or toxicity issues of other analogs.

With increasing resistance problems against medical antifungal compounds, class III HHKs have been considered as potential drug targets also against human fungal pathogens (Bahn et al., 2005; Nemecek et al., 2006; Chapeland-Leclerc et al., 2007; Randhawa et al., 2016), especially since the target is specific of the pathogen. Phenylpyrroles could constitute the next generation of clinical antifungals, but for this sector, we are not 
aware of any compound in clinical testing, although pyrrolnitrin served as lead structure for pharmaceutical research (e.g., Umio et al., 1969). The absence of clearly characterized molecular interaction between phenylpyrroles and class III HHKs may explain the absence of clinical analogs of phenylpyrroles or other inhibitors of these proteins. Inhibition studies of known protein kinases may help the identification of new antifungal molecules [e.g., in the model fungus N. crassa (Pillonel, 2005), the plant pathogenic fungus Ustilago maydis (Tueckmantel et al., 2011; Grutter et al., 2012), the human pathogenic fungi C. neoformans and C. albicans (Tsuda et al., 2011; Lee et al., 2015)], but phenylpyrrole-analogs do not figure among the tested molecules.

From a fundamental point of view, the activation of the osmotic ST pathway by phenylpyrroles also raises questions. Do

\section{REFERENCES}

Airola, M. V., Sukomon, N., Samanta, D., Borbat, P. P., Freed, J. H., Watts, K. J., et al. (2013). HAMP domain conformers that propagate opposite signals in bacterial chemoreceptors. PLoS Biol. 11:e1001479. doi: 10.1371/journal.pbio. 1001479

Airola, M. V., Watts, K. J., Bilwes, A. M., and Crane, B. R. (2010). Structure of concatenated HAMP domains provides a mechanism for signal transduction. Structure 18, 436-448. doi: 10.1016/j.str.2010.01.013

Ajouz, S., Bardin, M., Nicot, P. C., and El Maataoui, M. (2011). Comparison of the development in planta of a pyrrolnitrin-resistant mutant of Botrytis cinerea and its sensitive wild-type parent isolate. Eur. J. Plant Pathol. 129, 31-42. doi: 10.1007/s10658-010-9638-5

Ajouz, S., Nicot, P. C., and Bardin, M. (2010). Adaptation to pyrrolnitrin in Botrytis cinerea and cost of resistance. Plant Pathol. 59, 556-566. doi: 10.1111/j.13653059.2009.02230.x

Alberoni, G., Collina, M., Lanen, C., Leroux, P., and Brunelli, A. (2010). Field strains of Stemphylium vesicarium with a resistance to dicarboximide fungicides correlated with changes in a two-component histidine kinase. Eur. J. Plant Pathol. 128, 171-184. doi: 10.1007/s10658-010-9642-9

Aravind, L., and Ponting, C. P. (1999). The cytoplasmic helical linker domain of receptor histidine kinase and methyl-accepting proteins is common to many prokaryotic signalling proteins. FEMS Microbiol. Lett. 176, 111-116. doi: 10. 1111/j.1574-6968.1999.tb13650.x

Arima, K., Imanaka, H., Kousaka, M., Fukuda, A., and Tamura, G. (1965). Studies on pyrrolnitrin, a new antibiotic. I. Isolation and properties of pyrrolnitrin. J. Antibiot. (Tokyo) 18, 201-204.

Avenot, H., Simoneau, P., Iacomi-Vasilescu, B., and Bataille-Simoneau, N. (2005). Characterization of mutations in the two-component histidine kinase gene AbNIK1 from Alternaria brassicicola that confer high dicarboximide and phenylpyrrole resistance. Curr. Genet. 47, 234-243. doi: 10.1007/s00294-0050568-2

Avenot, H. F., and Michailides, T. J. (2015). Detection of isolates of Alternaria alternata with multiple-resistance to fludioxonil, cyprodinil, boscalid and pyraclostrobin in California pistachio orchards. Crop Prot. 78, 214-221. doi: 10.1016/j.cropro.2015.09.012

Bahn, Y.-S. (2008). Master and commander in fungal pathogens: the twocomponent system and the HOG signaling pathway. Eukaryot. Cell 7, 2017-2036. doi: 10.1128/ec.00323-08

Bahn, Y. S., Kojima, K., Cox, G. M., and Heitman, J. (2005). Specialization of the HOG pathway and its impact on differentiation and virulence of Cryptococcus neoformans. Mol. Biol. Cell 16, 2285-2300. doi: 10.1091/mbc.E04-11-0987

Bahn, Y. S., Kojima, K., Cox, G. M., and Heitman, J. (2006). A unique fungal two-component system regulates stress responses, drug sensitivity, sexual development, and virulence of Cryptococcus neoformans. Mol. Biol. Cell 17, 3122-3135. doi: 10.1091/mbc.E06-02-0113

Brigati, S., Gregori, R., Bianchi, P., and Serrati, L. (2009). "Fludioxonil: a new active substance for kiwifruit protection against post-harvest rots," in Proceedings of phenylpyrroles share the same ST elements as an hyperosmolarity treatment? If they bind to the class III HHK, what are the interacting domains? Do they differ from those recognizing hyperosmolarity (or dicarboximides)? Is resistance to fludioxonil conferred to by HHK loss-of-function mutations only, or are some of the mutations dominant active forms? These last questions require a thorough analysis of the ST processes after perception of phenylpyrroles, which may ultimately help understanding their mode of action.

\section{AUTHOR CONTRIBUTIONS}

JK and SF designed the plan of the manuscript. JK wrote sections $1-4$, SF wrote sections 5 and 6 and completed the review.

the IX Convegno Nazionale dell'Actinidia, Viterbo-Latina, Italia, 6-8 Ottobre (Firenze: Società di Ortoflorofrutticoltura Italiana), 285-289.

Catlett, N. L., Yoder, O. C., and Turgeon, B. G. (2003). Whole-genome analysis of two-component signal transduction genes in fungal pathogens. Eukaryot. Cell 2, 1151-1161. doi: 10.1128/EC.2.6.1151-1161.2003

Chapeland-Leclerc, F., Paccallet, P., Ruprich-Robert, G., Reboutier, D., Chastin, C., and Papon, N. (2007). Differential involvement of histidine kinase receptors in pseudohyphal development, stress adaptation, and drug sensitivity of the opportunistic yeast Candida lusitaniae. Eukaryot. Cell 6, 1782-1794. doi: 10. 1128/EC.00155-07

Corran, A., Knauf-Beiter, G., and Zeun, R. (2008). "Fungicides acting on signal transduction," in Modern Crop Protection Compounds, eds W. Krämer and U. Schirmer (Weinheim: Wiley-VCH Verlag GmbH), 561-580.

D’Aquino, S., Palma, A., Schirra, M., Continella, A., Tribulato, E., and La Malfa, S. (2010). Influence of film wrapping and fludioxonil application on quality of pomegranate fruit. Postharvest Biol. Technol. 55, 121-128. doi: 10.1016/j. postharvbio.2009.08.006

Defosse, T. A., Sharma, A., Mondal, A. K., Dugé de Bernonville, T., Latgé, J.-P., Calderone, R., et al. (2015). Hybrid histidine kinases in pathogenic fungi. Mol. Microbiol. 95, 914-924. doi: 10.1111/mmi.12911

Dongo, A., Bataille-Simoneau, N., Campion, C., Guillemette, T., Hamon, B., Iacomi-Vasilescu, B., et al. (2009). The group III two-component histidine kinase of filamentous fungi is involved in the fungicidal activity of the bacterial polyketide ambruticin. Appl. Environ. Microbiol. 75, 127-134. doi: 10.1128/ AEM.00993-08

Dry, I. B., Yuan, K. H., and Hutton, D. G. (2004). Dicarboximide resistance in field isolates of Alternaria alternata is mediated by a mutation in a two-component histidine kinase gene. Fungal Genet. Biol. 41, 102-108. doi: 10.1016/j.fgb.2003. 09.002

Duan, Y., Ge, C., Liu, S., Chen, C., and Zhou, M. (2013). Effect of phenylpyrrole fungicide fludioxonil on morphological and physiological characteristics of Sclerotinia sclerotiorum. Pestic. Biochem. Physiol. 106, 61-67. doi: 10.1016/j. pestbp.2013.04.004

Duan, Y.-B., Ge, C.-Y., and Zhou, M.-G. (2014). Molecular and biochemical characterization of Sclerotinia sclerotiorum laboratory mutants resistant to dicarboximide and phenylpyrrole fungicides. J. Pest Sci. 87, 221-230. doi: 10. 1007/s10340-013-0526-6

Edmunds, B. A., and Holmes, G. J. (2009). Evaluation of alternative decay control products for control of postharvest Rhizopus soft rot of sweetpotatoes. Plant Health Prog. (in press). doi: 10.1094/PHP-2009-0206-01-RS

Errampalli, D. (2004). Effect of fludioxonil on germination and growth of Penicillium expansum and decay in apple cvs. Empire and Gala. Crop Prot. 23, 811-817. doi: 10.1016/j.cropro.2003.12.010

Faretra, F., and Pollastro, S. (1993). Isolation, characterization and genetic analysis of laboratory mutants of Botryotinia fuckeliana resistant to the phenylpyrrole fungicide CGA 173506. Mycol. Res. 97, 620-624. doi: 10.1016/s0953-7562(09) 81187-8 
Fillinger, S., Ajouz, S., Nicot, P. C., Leroux, P., and Bardin, M. (2012). Functional and structural comparison of pyrrolnitrin- and iprodione-induced modifications in the class III histidine-kinase Bos1 of Botrytis cinerea. PLoS ONE 7:e42520. doi: 10.1371/journal.pone.0042520

Fillinger, S., and Walker, A.-S. (2016). "Chemical control and resistance management of Botrytis diseases," in Botrytis - the Fungus, the Pathogen and its Management in Agricultural Systems, eds S. Fillinger and Y. Elad (Cham: Springer International Publishing), 189-216.

Firoz, M. J., Xiao, X., Zhu, F. X., Fu, Y. P., Jiang, D. H., Schnabel, G., et al. (2015). Exploring mechanisms of resistance to dimethachlone in Sclerotinia sclerotiorum. Pest Manag. Sci. 72, 770-779. doi: 10.1002/ps.4051

Floss, H. G., Manni, P. E., Hamill, R. L., and Mabe, J. A. (1971). Further studies on the biosynthesis of pyrrolnitrin from tryptophan by Pseudomonas. Biochem. Biophys. Res. Commun. 45, 781-787. doi: 10.1016/0006-291x(71) 90485-2

Förster, H., Driever, G. F., Thompson, D. C., and Adaskaveg, J. E. (2007). Postharvest decay management for stone fruit crops in California using the "reduced-risk" fungicides fludioxonil and fenhexamid. Plant Dis. 91, 209-215. doi: 10.1094/pdis-91-2-0209

Foureau, E., Clastre, M., Montoya, E. J. O., Besseau, S., Oudin, A., Glevarec, G., et al. (2014). Subcellular localization of the histidine kinase receptors $\operatorname{Sin} 1$ p, Niklp and Chk1p in the yeast CTG clade species Candida guilliermondii. Fungal Genet. Biol. 65, 25-36. doi: 10.1016/j.fgb.2014.01.007

Fujimura, M., Ochiai, N., Ichiichi, A., Usami, R., Horikoshi, K., and Yamaguchi, I. (2000). Sensitivity to phenylpyrrole fungicides and abnormal glycerol accumulation in os and cut mutant strains of Neurospora crassa. J. Pestic. Sci. 25, 31-36. doi: 10.1584/jpestics.25.31

Fujimura, M., Ochiai, N., Oshima, M., Motoyama, T., Ichiishi, A., Usami, R., et al. (2003). Putative homologs of SSK22 MAPKK kinase and PBS2 MAPK kinase of Saccharomyces cerevisiae encoded by os -4 and os -5 genes for osmotic sensitivity and fungicide resistance in Neurospora crassa. Biosci. Biotechnol. Biochem. 67, 186-191. doi: 10.1271/bbb.67.186

Furukawa, K., Randhawa, A., Kaur, H., Mondal, A. K., and Hohmann, S. (2012). Fungal fludioxonil sensitivity is diminished by a constitutively active form of the group III histidine kinase. FEBS Lett. 586, 2417-2422. doi: 10.1016/j.febslet. 2012.05.057

Gachango, E., Hanson, L. E., Rojas, A., Hao, J. J., and Kirk, W. W. (2012). Fusarium spp. causing dry rot of seed potato tubers in Michigan and their sensitivity to fungicides. Plant Dis. 96, 1767-1774. doi: 10.1094/pdis-11-11-0932-re

Gehmann, K., Nyfeler, R., Leadbeater, A. J., Nevill, D. J., and Sozzi, D. (1990). “CGA 173506: a new phenylpyrrole fungicide for broad-spectrum disease control," in Brighton Crop Protection Conference, Pests and Diseases - 1990, Vol. 2, (Alton: British Crop Protection Council), 399-406.

Grutter, C., Simard, J. R., Mayer-Wrangowski, S. C., Schreier, P. H., PerezMartin, J., Richters, A., et al. (2012). Targeting GSK3 from Ustilago maydis: type-II kinase inhibitors as potential antifungals. ACS Chem. Biol. 7, 1257-1267. doi: $10.1021 / \mathrm{cb} 300128$ b

Hagiwara, D., Matsubayashi, Y., Marui, J., Furukawa, K., Yamashino, T., Kanamaru, K., et al. (2007). Characterization of the NikA histidine kinase implicated in the phosphorelay signal transduction of Aspergillus nidulans, with special reference to fungicide responses. Biosci. Biotechnol. Biochem. 71, 844-847. doi: 10.1271/bbb.70051

Herivaux, A., So, Y. S., Gastebois, A., Latge, J. P., Bouchara, J. P., Bahn, Y. S., et al. (2016). Major sensing proteins in pathogenic fungi: the hybrid histidine kinase family. PLoS Pathog. 12:e1005683. doi: 10.1371/journal.ppat.10 05683

Hohmann, S. (2002). Osmotic stress signaling and osmoadaptation in yeasts. Microbiol. Mol. Biol. Rev. 66, 300-372. doi: 10.1128/MMBR.66.2.300-372.2002

Howell, C. R., and Stipanovic, R. D. (1979). Control of Rhizoctonia solani on cotton seedlings with Pseudomonas fluorescens and with an antibiotic produced by the bacterium. Phytopathology 69, 480-482. doi: 10.1094/Phyto-69-480

Iacomi-Vasilescu, B., Avenot, H., Bataillé-Simoneau, N., Laurent, E., Guénard, M., and Simoneau, P. (2004). In vitro fungicide sensitivity of Alternaria species pathogenic to crucifers and identification of Alternaria brassicicola field isolates highly resistant to both dicarboximides and phenylpyrroles. Crop Prot. 23, 481-488. doi: 10.1016/j.cropro.2003.10.003

Iacomi-Vasilescu, B., Bataille-Simoneau, N., Campion, C., Dongo, A., Laurent, E., Serandat, I., et al. (2008). Effect of null mutations in the AbNIK1 gene on saprophytic and parasitic fitness of Alternaria brassicicola isolates highly resistant to dicarboximide fungicides. Plant Pathol. 57, 937-947. doi: 10.1111/j. 1365-3059.2008.01864.x

Imanaka, H., Kousaka, M., Tamura, G., and Arima, K. (1965). Studies on pyrrolnitrin, a new antibiotic. 3. Structure of pyrrolnitrin. J. Antibiot. (Tokyo) $18,207-210$.

Jespers, A. B. K., Davidse, L. C., and De Waard, M. A. (1994). Interference of the phenylpyrrole fungicide fenpiclonil with membranes and membrane function. Pestic. Sci. 40, 133-140. doi: 10.1002/ps.2780400208

Jespers, A. B. K., Davidse, L. C., and Dewaard, M. A. (1993). Biochemical effects of the phenylpyrrole fungicide fenpiclonil in Fusarium sulphureum (Schlecht). Pestic. Biochem. Physiol. 45, 116-129. doi: 10.1006/pest.1993.1014

Jespers, A. B. K., and De Waard, M. A. (1995). Effect of fenpiclonil on phosphorylation of glucose in Fusarium sulphureum. Pestic. Sci. 44, 167-175. doi: $10.1002 / \mathrm{ps} .2780440210$

Jespers, B. K., and De Waard, M. A. (1994). Effect of fenpiclonil on macromolecule biosynthesis in Fusarium sulphureum. Pestic. Biochem. Physiol. 49, 53-62. doi: $10.1006 /$ pest.1994.1033

Judewicz, N. D., Glikin, G. C., and Torres, H. N. (1981). Protein kinase activities in Neurospora crassa. Arch. Biochem. Biophys. 206, 87-92. doi: 10.1016/00039861(81)90069-2

Jung, K., Fried, L., Behr, S., and Heermann, R. (2012). Histidine kinases and response regulators in networks. Curr. Opin. Microbiol. 15, 118-124. doi: 10. 1016/j.mib.2011.11.009

Kanetis, L., Förster, H., and Adaskaveg, J. E. (2007). Comparative efficacy of the new postharvest fungicides azoxystrobin, fludioxonil, and pyrimethanil for managing citrus green mold. Plant Dis. 91, 1502-1511. doi: 10.1094/pdis-9111- 1502

Klose, D., Voskoboynikova, N., Orban-Glass, I., Rickert, C., Engelhard, M., Klare, J. P., et al. (2014). Light-induced switching of HAMP domain conformation and dynamics revealed by time-resolved EPR spectroscopy. FEBS Lett. 588, 3970-3976. doi: 10.1016/j.febslet.2014.09.012

Kojima, K., Takano, Y., Yoshimi, A., Tanaka, C., Kikuchi, T., and Okuno, T. (2004). Fungicide activity through activation of a fungal signalling pathway. Mol. Microbiol. 53, 1785-1796. doi: 10.1111/j.1365-2958.2004. 04244.x

Kretschmer, M., Leroch, M., Mosbach, A., Walker, A. S., Fillinger, S., Mernke, D., et al. (2009). Fungicide-driven evolution and molecular basis of multidrug resistance in field populations of the grey mould fungus Botrytis cinerea. PLoS Pathog. 5:e1000696. doi: 10.1371/journal.ppat.1000696

Lavin, J. L., Ramirez, L., Ussery, D. W., Pisabarro, A. G., and Oguiza, J. A. (2010). Genomic analysis of two-component signal transduction proteins in basidiomycetes. J. Mol. Microbiol. Biotechnol. 18, 63-73. doi: 10.1159/ 000277654

Leadbitter, N. J., Nyfeler, R., and Elmsheuser, H. (1994). “The phenylpyrroles: the history of their development at Ciba," in Proceedings of a Symposium held at the University of Kent, Canterbury, 129-134.

Lee, W. J., Moon, J. S., Kim, S. I., Bahn, Y. S., Lee, H., Kang, T. H., et al. (2015). A phenylpropanoid glycoside as a calcineurin inhibitor isolated from Magnolia obovata Thunb. J. Microbiol. Biotechnol. 25, 1429-1432. doi: 10.4014/jmb.1506. 06031

Leroch, M., Plesken, C., Weber, R. W., Kauff, F., Scalliet, G., and Hahn, M. (2013). Gray mold populations in german strawberry fields are resistant to multiple fungicides and dominated by a novel clade closely related to Botrytis cinerea. Appl. Environ. Microbiol. 79, 159-167. doi: 10.1128/AEM. 02655-12

Leroux, P. (1996). Recent developments in the mode of action of fungicides. Pestic. Sci. 47, 191-197. doi: 10.1002/(SICI)1096-9063(199606)47:2\$<\$191:: AID-PS415\$>\$3.3.CO;2-9

Leroux, P., Fritz, R., Debieu, D., Albertini, C., Lanen, C., Bach, J., et al. (2002). Mechanisms of resistance to fungicides in field strains of Botrytis cinerea. Pest Manag. Sci. 58, 876-888. doi: 10.1002/ps.566

Leroux, P., Lanen, C., and Fritz, R. (1992). Similarities in the antifungal activities of fenpiclonil, iprodione and tolclofos-methyl against Botrytis cinerea and Fusarium nivale. Pestic. Sci. 36, 255-261. doi: 10.1002/ps.2780 360312

Lew, R. R. (2010). Turgor and net ion flux responses to activation of the osmotic MAP kinase cascade by fludioxonil in the filamentous fungus 
Neurospora crassa. Fungal Genet. Biol. 47, 721-726. doi: 10.1016/j.fgb.2010. 05.007

Luo, Y. Y., Yang, J. K., Zhu, M. L., Liu, C. J., Li, H. Y., Lu, Z. B., et al. (2012). The group III two-component histidine kinase AlHK1 is involved in fungicides resistance, osmosensitivity, spore production and impacts negatively pathogenicity in Alternaria longipes. Curr. Microbiol. 64, 449-456. doi: 10.1007/ s00284-012-0093-8

Ma, Q., Roy, F., Herrmann, S., Taylor, B. L., and Johnson, M. S. (2004). The Aer protein of Escherichia coli forms a homodimer independent of the signaling domain and flavin adenine dinucleotide binding. J. Bacteriol. 186, 7456-7459. doi: 10.1128/JB.186.21.7456-7459.2004

Malandrakis, A. A., Apostolidou, Z. A., Markoglou, A., and Flouri, F. (2015). Fitness and cross-resistance of Alternaria alternata field isolates with specific or multiple resistance to single site inhibitors and mancozeb. Eur. J. Plant Pathol. 142, 489-499. doi: 10.1007/s10658-015-0628-5

Matamouros, S., Hager, K. R., and Miller, S. I. (2015). HAMP domain rotation and tilting movements associated with signal transduction in the PhoQ sensor kinase. MBio 6:e00616-15. doi: 10.1128/mBio.00616-15

Meena, N., Kaur, H., and Mondal, A. K. (2010). Interactions among HAMP domain repeats act as an osmosensing molecular switch in group III hybrid histidine kinases from fungi. J. Biol. Chem. 285, 12121-12132. doi: 10.1074/jbc.M109. 075721

Motoyama, T., Kadokura, K., Ohira, T., Ichiishi, A., Fujimura, M., Yamaguchi, I., et al. (2005). A two-component histidine kinase of the rice blast fungus is involved in osmotic stress response and fungicide action. Fungal Genet. Biol. 42, 200-212. doi: 10.1016/j.fgb.2004.11.002

Mueller, D. S., Hartman, G. L., and Pedersen, W. L. (1999). Development of sclerotia and apothecia of Sclerotinia sclerotiorum from infected soybean seed and its control by fungicide seed treatment. Plant Dis. 83, 1113-1115. doi: 10.1094/pdis.1999.83.12.1113

Nemecek, J. C., Wuthrich, M., and Klein, B. S. (2006). Global control of dimorphism and virulence in fungi. Science 312, 583-588. doi: 10.1126/science. 1124105

Ochiai, N., Fujimura, M., Motoyama, T., Ichiishi, A., Usami, R., Horikoshi, K., et al. (2001). Characterization of mutations in the two-component histidine kinase gene that confer fludioxonil resistance and osmotic sensitivity in the os1 mutants of Neurospora crassa. Pest. Manag. Sci. 57, 437-442. doi: 10.1002/ ps.302

Olaya, G., Abawi, G. S., and Barnard, J. (1994). Response of Rhizoctonia solani and Binucleate rhizoctonia to five fungicides and control of pocket rot of table beets with foliar sprays. Plant Dis. 78, 1033-1037. doi: 10.1094/PD78-1033

Oshima, M., Banno, S., Okada, K., Takeuchi, T., Kimura, M., Ichiishi, A., et al. (2006). Survey of mutations of a histidine kinase gene BcOS1 in dicarboximideresistant field isolates of Botrytis cinerea. J. Gen. Plant Pathol. 72, 65-73. doi: 10.1094/PHYTO-98-4-0397

Oshima, M., Fujimura, F., Banno, S., Hashimoto, C., Motoyama, T., Ichiishi, A., et al. (2002). A point mutation in the two-component histidine kinase BcOS1 gene confers dicarboximide resistance in field isolates of Botrytis cinerea. Phytopathology 92, 75-80. doi: 10.1094/PHYTO.2002.92.1.75

Palou, L., Crisosto, C. H., and Garner, D. (2007). Combination of postharvest antifungal chemical treatments and controlled atmosphere storage to control gray mold and improve storability of 'Wonderful' pomegranates. Postharvest Biol. Technol. 43, 133-142. doi: 10.1016/j.postharvbio.2006.08.013

Parkinson, J. S. (2010). Signaling mechanisms of HAMP domains in chemoreceptors and sensor kinases. Annu. Rev. Microbiol. 64, 101-122. doi: 10.1146/annurev.micro.112408.134215

Perkins, D. D., Radford, A., Newmeyer, D., and Björkman, M. (1982). Chromosomal loci of Neurospora crassa. Microbiol. Rev. 46, 426-570.

Pillonel, C. (2005). Evaluation of phenylaminopyrimidines as antifungal protein kinase inhibitors. Pest. Manag. Sci. 61, 1069-1076. doi: 10.1002/ ps. 1080

Pillonel, C., and Meyer, T. (1997). Effect of phenylpyrroles on glycerol accumulation and protein kinase activity of Neurospora crassa. Pestic. Sci. 49, 229-236. doi: 10.1002/(SICI)1096-9063(199703)49:3\$<\$229::AID-PS525\$>\$3. $0 . \mathrm{CO} ; 2-\mathrm{T}$
Randhawa, A., Chawla, S., and Mondal, A. K. (2016). Functional dissection of HAMP domains in NIK1 ortholog from pathogenic yeast Candida lusitaniae. Gene 577, 251-257. doi: 10.1016/j.gene.2015.12.002

Ren, W., Shao, W., Han, X., Zhou, M., and Chen, C. (2016). Molecular and biochemical characterization of laboratory and field mutants of Botrytis cinerea resistant to fludioxonil. Plant Dis. 100, 1414-1423. doi: 10.1094/pdis-11-151290-re

Rupp, S., Weber, R. W., Detzel, P., Rieger, D., and Hahn, M. (2016). Spread of Botrytis cinerea strains with multiple fungicide resistance in German horticulture. Front. Microbiol. 7:2075. doi: 10.3389/fmicb.2016.02075

Schultz, J. E., Kanchan, K., and Ziegler, M. (2015). Intraprotein signal transduction by HAMP domains: a balancing act. Int. J. Med. Microbiol. 305, 243-251. doi: 10.1016/j.ijmm.2014.12.007

Schumacher, M. M., Enderlin, C. S., and Selitrennikoff, C. P. (1997). The osmotic1 locus of Neurospora crassa encodes a putative histidine kinase similar to osmosensors of bacteria and yeast. Curr. Microbiol. 34, 340-347. doi: 10.1007/ s002849900193

Segmuller, N., Ellendorf, U., Tudzynski, B., and Tudzynski, P. (2007). BcSAK1, a stress-activated mitogen-activated protein kinase, is involved in vegetative differentiation and pathogenicity in Botrytis cinerea. Eukaryot. Cell 6, 211-221. doi: 10.1128/ec.00153-06

Taguchi, H., Suzuki, H., and Kuroda, K. (2012). A system to control Glomerella cingulata on strawberry by using fungicides on the basis of their residual activity. Annu. Rep. Kansai Plant Prot. Soc. 54, 53-59. doi: 10.4165/kapps. 54.53

Tanaka, C., and Izumitsu, K. (2010). "Two-component signaling system in filamentous fungi and the mode of action of dicarboximide and phenylpyrrol fungicides," in Fungicides, ed. O. Carisse (Rijeka: InTech), 523-538.

Tsuda, K., Nishiya, N., Umeyama, T., and Uehara, Y. (2011). Identification of LY83583 as a specific inhibitor of Candida albicans MPS1 protein kinase. Biochem. Biophys. Res. Commun. 409, 418-423. doi: 10.1016/j.bbrc.2011. 05.010

Tueckmantel, S., Greul, J. N., Janning, P., Brockmeyer, A., Gruetter, C., Simard, J. R., et al. (2011). Identification of Ustilago maydis aurora kinase as a novel antifungal target. ACS Chem. Biol. 6, 926-933. doi: 10.1021/cb2 $00112 y$

Twizeyimana, M., McDonald, V., Mayorquin, J. S., Wang, D. H., Na, F., Akgül, D. S., et al. (2013). Effect of fungicide application on the management of avocado branch canker (Formerly Dothiorella Canker) in California. Plant Dis. 97, 897-902. doi: 10.1094/pdis-06-12-0518-re

Ulloa, R. M., Glikin, G. C., Tellez-Inon, M. T., Torres, H. N., and Judewicz, N. D. (1987). A novel stimulator of protein phosphorylation in Neurospora crassa. Mol. Cell. Biochem. 77, 11-17. doi: 10.1007/BF002 30146

Umio, S., Kariyone, K., Tanaka, K., and Nakamura, H. (1969). Total synthesis of pyrrolnitrin. I. synthesis of 3-arylpyrrole derivatives by knorrs condensation. Chem. Pharm. Bull. 17, 559-566. doi: 10.1248/cpb. 17.559

Viaud, M., Fillinger, S., Liu, W., Polepalli, J. S., Le Pecheur, P., Kunduru, A. R., et al. (2006). A class III histidine kinase acts as a novel virulence factor in Botrytis cinerea. Mol. Plant Microbe Interact. 19, 1042-1050. doi: 10.1094/mpmi-191042

Walker, A.-S., Micoud, A., Rémuson, F., Grosman, J., Gredt, M., and Leroux, P. (2013). French vineyards provide information that opens ways for effective resistance management of Botrytis cinerea (grey mould). Pest. Manag. Sci. 69, 667-678. doi: 10.1002/ps.3506

Yoshimi, A., Kojima, K., Takano, Y., and Tanaka, C. (2005). Group III histidine kinase is a positive regulator of Hog1-type mitogen-activated protein kinase in filamentous fungi. Eukaryot. Cell 4, 1820-1828. doi: 10.1128/EC.4.11.18201828.2005

Zhang, Y., Lamm, R., Pillonel, C., Lam, S., and Xu, J. R. (2002). Osmoregulation and fungicide resistance: the Neurospora crassa os-2 gene encodes a HOG1 mitogenactivated protein kinase homologue. Appl. Environ. Microbiol. 68, 532-538. doi: 10.1128/AEM.68.2.532-538.2002

Zhao, H., Kim, Y. K., Huang, L., and Xiao, C. L. (2010). Resistance to thiabendazole and baseline sensitivity to fludioxonil and pyrimethanil in Botrytis cinerea 
populations from apple and pear in Washington state. Postharvest Biol. Technol. 56, 12-18. doi: 10.1016/j.postharvbio.2009.11.013

Zhou, Q., Ames, P., and Parkinson, J. S. (2009). Mutational analyses of HAMP helices suggest a dynamic bundle model of input-output signalling in chemoreceptors. Mol. Microbiol. 73, 801-814. doi: 10.1111/j.1365-2958.2009. 06819.x

Ziogas, B. N., Markoglou, A. N., and Spyropoulou, V. (2005). Effect of phenylpyrrole-resistance mutations on ecological fitness of Botrytis cinerea and their genetical basis in Ustilago maydis. Eur. J. Plant Pathol. 113, 83-100. doi: 10.1007/s10658-005-1227-7
Conflict of Interest Statement: The authors declare that the research was conducted in the absence of any commercial or financial relationships that could be construed as a potential conflict of interest.

Copyright (C) 2016 Kilani and Fillinger. This is an open-access article distributed under the terms of the Creative Commons Attribution License (CC BY). The use, distribution or reproduction in other forums is permitted, provided the original author(s) or licensor are credited and that the original publication in this journal is cited, in accordance with accepted academic practice. No use, distribution or reproduction is permitted which does not comply with these terms. 